\title{
Phytochemicals as Protectors Against Ultraviolet Radiation: Versatility of Effects and Mechanisms
}

Author

Affiliation

\author{
Albena T. Dinkova-Kostova
}

Biomedical Research Centre, Ninewells Hospital and Medical School, University of Dundee, Scotland, UK and Department of Pharmacology and Molecular Sciences and Department of Medicine, Johns Hopkins University, Baltimore, Maryland, USA

\author{
Key words \\ - caffeine \\ - epigallocatechin 3-gallate \\ - lycopene \\ - silibinin \\ - skin cancer \\ - sulforaphane
}

received March 26, 2008

revised May 16, 2008

accepted May 22, 2008

\section{Bibliography}

DOI 10.1055/s-2008-1081296

Planta Med 2008; 74: 1548-

1559

๑) Georg Thieme Verlag KG Stuttgart · New York Published online August 11, 2008

ISSN 0032-0943

\section{Correspondence}

Albena T. Dinkova-Kostova

University of Dundee

Biomedical Research Centre

Ninewells Hospital and Medical

School, Level 5

Dundee DD1 9SY

Scotland

United Kingdom

Tel.: +44-1382-740-045

Fax: +44-1382-669-993

a.dinkovakostova@

dundee.ac.uk

\section{Abstract \\ $\nabla$}

Ultraviolet (UV) radiation is one of the most abundant carcinogens in our environment, and the development of non-melanoma skin cancers, the most common type of human malignancy worldwide, represents one of the major consequences of excessive exposure. Because of growing concerns that the level of UV radiation is increasing as a result of depletion of the stratospheric ozone and climate change, the development of strategies for protection of the skin is an urgent need. Many phytochemicals that belong to various families of secondary metabolites, such as alkaloids (caffeine, sanguinarine), flavonoids [(-)-epigallocatechin 3-gallate, genistein, silibinin], carotenoids ( $\beta$-carotene, lycopene), and isothiocyanates (sulforaphane), offer exciting platforms for the development of such protective strategies. These phytochemicals have been consumed by humans for many centuries as part of plant-rich diets and are presumed to be of low toxicity, an essential requirement for a chemoprotective agent. Mechanistically, they affect multiple signalling pathways and protect against UV radiation-inflicted damage by their ability to act as direct and indirect antioxidants, as well as anti-inflammatory and immunomodulatory agents. Such "pluripotent character" is a critical prerequisite for an agent that is designed to counteract the multiple damaging effects of UV radiation. Especially attractive are inducers

\section{The Multiple Damaging Effects of UV Radiation \\ $\nabla$}

Plants and animals have evolved utilizing the beneficial effects of sunlight for fundamental processes such as photosynthesis and vision. Paradoxically, the ultraviolet (UV) component of the solar spectrum represents one of the most ubiq- of the Keap1/Nrf2/ARE pathway, which controls the gene expression of proteins whose activation leads to enhanced protection against oxidants and electrophiles. Such protection is comprehensive, long-lasting, and unlikely to cause pro-oxidant effects or interfere with the synthesis of vitamin D.

\section{Abbreviations \\ $\nabla$}

AP-1: activator protein 1

ARE: antioxidant response element

COX-2: cyclooxygenase 2

EGG: epigallocatechin 3-gallate

EGF: epidermal growth factor

GSH: glutathione

iNOS: inducible nitric oxide synthase

Keap1: Kelch-like ECH-associated protein 1

IL: inerleukin

MAPK: mitogen-activated protein kinase

MMP: matrix metalloprotease

$\mathrm{NF}-\kappa \mathrm{B}: \quad$ nuclear factor- $\kappa \mathrm{B}$

NQO1: NAD(P)H:quinone oxidoreductase 1

Nrf2: nuclear factor-erythroid 2-related factor 2

ODC: $\quad$ ornithine decarobxylase

PCNA: proliferating cell nuclear antigen

ROS: $\quad$ reactive oxygen species

TPA: 12-O-tetradecanoylphorbol 13-acetate UV: ultraviolet uitous carcinogens in our environment. Furthermore, there is growing concern that its levels are increasing as a result of depletion of the stratospheric ozone and climate change [1], [2], [3]. Based on wavelength, the UV spectrum is commonly divided into three regions: UVA (400$320 \mathrm{~nm})$, UVB (320-290 nm), and UVC (290$200 \mathrm{~nm}$ ). The UVC component is highly mutagen- 
ic, but it is filtered by the ozone layer, whereas UVA and UVB reach the surface of the Earth. Because of their intrinsic absorption properties, endogenous nucleotide bases, flavins, porphyrins, and amino acids and their derivatives, such as urocanic acid, can serve as chromophores and photosensitizing agents [4], [5], [6]. UVA represents more than $90 \%$ of the solar UV radiation that reaches the surface of the Earth [7] and, consisting of longer wavelengths, penetrates more deeply into tissues than UVB does [8]. The UV doses that terrestrial organisms are exposed to increase with increasing altitude, decreasing latitude, and ozone depletion. It has been estimated that outdoor- and indoor-working individuals receive $\sim 10 \%$ and $3 \%$ of the total available annual UV radiation, respectively, and that most people get $10,000-20,000 \mathrm{~J} / \mathrm{m}^{2}$ per year (Europe), $20,000-30,000 \mathrm{~J} / \mathrm{m}^{2}$ per year (United States), and $20,000-50,000 \mathrm{~J} / \mathrm{m}^{2}$ per year (Australia) [9].

Being directly exposed to sunlight, the human eye and skin are subject to acute and chronic damage inflicted by UV radiation. Thus, pterygium, photokeratitis, age-related macular degeneration, and cataract are examples of human ocular diseases in the pathogenesis of which UV radiation has been implicated, whereas sunburn, photoaging, and the development of various types of skin cancers are examples of the consequences of excessive exposure of the skin to UV radiation [3], [10]. This review focuses on the damaging effects of UV radiation to the skin that can potentially lead to skin cancer. Non-melanoma skin cancers are the most common types of cancer, and more than 1 million new cases per year are being reported in the United States [11], [12]. According to estimates of the National Cancer Institute, $40-50 \%$ of Americans who live to age 65 will develop skin cancer at least once, and the risk of developing additional tumors is high [13]. Both UVA and UVB radiation contribute to the development of human skin cancers. One of the immediate consequences of exposure to UV radiation is DNA damage, which, if unrepaired, can lead to mutations and neoplasia. Indeed, the development of the majority of skin cancers can be attributed to chronic exposure to UV radiation. This is reflected by the anatomical distribution of skin cancers that largely occur on sun-exposed areas. Susceptibility to cancer associated with defective DNA repair is best exemplified in the hereditary syndrome xeroderma pigmentosum, a complex of autosomal recessive disorders leading to extreme photosensitivity and early onset of cutaneous malignancies. Compared with the general population, xeroderma pigmentosum patients cannot repair UV radiation-induced DNA damage efficiently and are at more than 1000-fold increased risk for skin cancer [14].
The damaging effects of UV radiation are multiple ( $\bullet$ Fig. 1). Thus, UV radiation causes direct DNA damage, for example, formation of cyclobutane-pyrimidine dimers and pyrimidine (6-4) pyrimidone photoproducts [15], [16]. The resulting mutations (characterized by $\mathrm{C}$ to $\mathrm{T}$ or CC to TT transitions) are known as "signatures" of sun exposure [17] and have been detected in proto-oncogenes (ras) and in tumor suppressor genes (p53 and $P T C H$ ) in tumor samples of skin cancer patients [17], [18], [19], [20], [21]. UVA radiation is also genotoxic and can be further subdivided into UVA1 (340-400 nm) and UVA2 (320-340 nm). It is believed that the DNA-damaging effects of UVA1 are indirect, through the generation of radical and non-radical reactive oxygen species (ROS), while UVA2 can cause damage both indirectly through ROS and directly through the formation of DNA photoproducts. The predominant ROS produced upon UVA radiation are singlet oxygen $\left({ }^{1} \mathrm{O}_{2}\right)$ and, to a small extent, hydroxyl radical $\left(\mathrm{OH}^{\circ}\right)$ [16], which can potentially lead to oxidative damage of DNA (e.g., formation of 8-oxo-7,8-dihydro-2'-deoxyguanosine and thymidine glycol), to lipid peroxidation, and to cross-linking of proteins such as collagen [7], [22]. Curiously, in human skin exposed to UVA radiation, cyclobutane pyrimidine dimers are produced in significant yield and in even larger amounts than 8-oxo7,8-dihydro-2'-deoxyguanosine, and their rate of removal is lower than those produced by UVB radiation [23]. Because cyclobutane pyrimidine dimers are more efficient in blocking the progression of DNA polymerase than pyrimidine (6-4) pyrimidone photoproducts, they have fewer lethal and more mutagenic effects [8], pointing to the importance of the UVA component of the UV spectrum in the photocarcinogenesis of the skin. In addition, under conditions of chronic low-dose UV radiation, epidermal stem and progenitor cells accumulate cyclobutane pyrimidine dimers despite their proficiency in nucleotide excision repair [24]. Growth stimulation of these cells gives rise to genomic instability that is propagated in their daughter cells and is accompanied by overexpression of wild-type p53 [25].

In vivo and in vitro experiments have demonstrated that multiple signalling pathways are affected depending on the type, radiant dose, and multiplicity of UV radiation. Upon DNA damage, the tumor suppressor p53 undergoes phosphorylation and nuclear translocation, causing cell cycle arrest, which is followed either by repair of the damaged site(s) or, in cases of extensive damage, by apoptosis [26]. However, DNA damage leading to mutations in p53 can render keratinocytes resistant to apoptosis and allow them to proliferate. UVA radiation-generated singlet oxygen activates mitogen-activated protein kinase (MAPK) pathways [27], [28], [29]. The nuclear factor $-\kappa \mathrm{B}(\mathrm{NF}-\kappa \mathrm{B})$ and activator

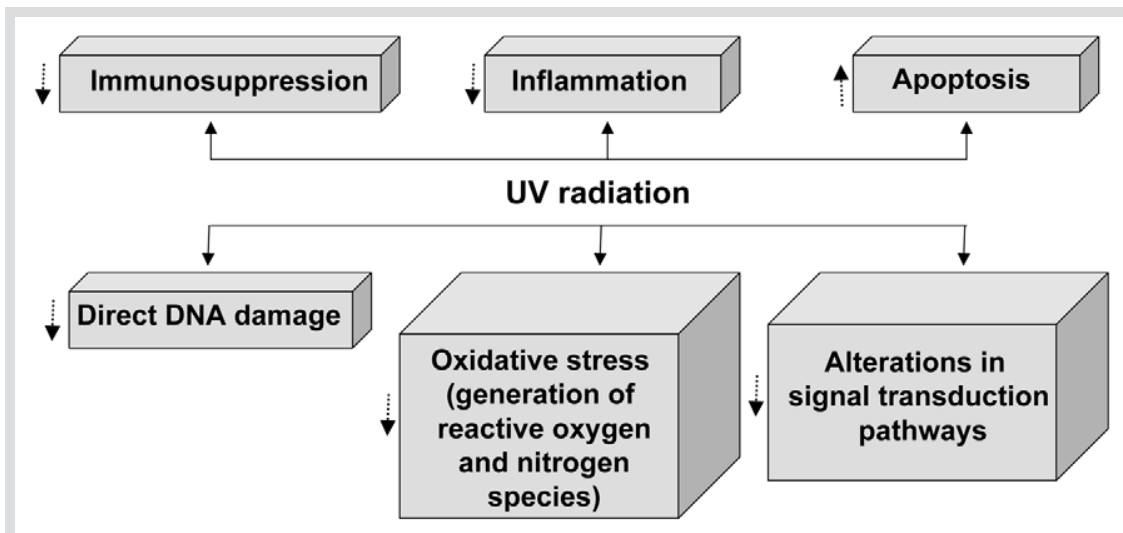

Fig. 1 The multiple damaging effects of UV radiation. UV radiation causes direct DNA damage as well as oxidative stress, leading to oxidative damage of DNA, proteins, and lipids. In addition, UV radiation alters various signal transduction pathways and leads to inflammation, immunosuppression, and apoptosis. The phytochemicals discussed in this review can protect against UV radiation-inflicted damage (dashed arrows) by direct absorption (light filtering); inhibition of chronic inflammation; modulation of immunosuppression; induction of apoptosis; scavenging of reactive oxygen and nitrogen species (direct antioxidant activity); and activation of intrinsic enzymatic defenses that detoxify oxidants and electrophiles (indirect antioxidant activity). 
protein-1 (AP-1) families of transcription factor are then activated [28], [29], [30]. Because of their functions in the regulation of the expression of genes that are involved in fundamental cellular processes such as proliferation, differentiation, and survival, modulations of their levels and activities constitute important factors that may contribute to inflammation, angiogenesis, and tumor development.

In addition to, and sometimes as a consequence of, direct and oxidative damage to biological macromolecules and alterations of signal transduction pathways, exposure to UV radiation causes inflammation as well as local and systemic immunosuppression in both animals and humans [31], [32]. Alterations in the morphology and function of antigen-presenting Langerhans cells, release of immunosuppressive cytokines, and enhanced prostaglandin synthesis have all been reported [33], [34], [35]. UV radiation challenge leads to an increase in intracellular free $\mathrm{Ca}^{2+}$ in keratinocytes, resulting in activation of the inflammasome (a multiprotein innate immune complex) and synthesis and release of interleukin-1 (IL-1) [36], which can then trigger the synthesis of other proinflammatory cytokines [37], [38]. Recently Yano et al. [39] characterized the temporal transcriptional changes in human epidermal keratinocytes following treatment with IL- $1 \alpha$ and found that this cytokine has numerous targets, such as other secreted cytokines, chemokines, growth factors, and their receptors, with broad implications to inflammatory responses. Thus, release of IL-6 and IL-8 induces further inflammation [40]. UV radiation exerts its immunosuppressive effects in several different ways by (i) inhibiting the function of antigen-presenting cells, (ii) inducing T cells with suppressor activity, and (iii) causing the release of immunosuppressive cytokines [41]. IL-10 appears to be a key mediator of UV radiation-induced immunosuppression. Thus, splenic regulatory T cells from UV-irradiated interleukin-10 (IL-10) knockout mice were unable to confer immunosuppression upon transfer into naive recipients. Moreover, IL10 knockout mice are protected against UV radiation-induced photocarcinogenesis of the skin [42].

In contrast to the effects of IL-10, intraperitoneal injection of interleukin-12 (IL-12) prevents UVB radiation-induced local immunosuppression [43]. Conversely, administration of an antiIL-12 antibody inhibits sensitization and induces hapten-specific tolerance [44]. Importantly, IL-12 was found to accelerate the removal of UV-induced DNA lesions in keratinocytes by inducing nucleotide-excision repair, strongly suggesting that it plays a protective role in photocarcinogenesis of the skin [45]. Indeed, exposure to UV radiation of mice that lack the IL-12p40 chain and thus do not secrete biologically active IL-12 led to a higher load of UV radiation-induced pyrimidine dimers in their skin and development of tumors characterized by higher multiplicity that, when transplanted into nude mice, grew faster than the corresponding tumors in wild-type control animals [46].

One of the clinically detectable consequences of UV radiation damage to the skin in humans is erythema. It occurs early (within $24 \mathrm{~h}$ after exposure to UV radiation) [47], [48] and can be visually assessed and further objectively quantified using reflectance spectroscopy [49], [50]. Furthermore, erythema is considered to be a biomarker of skin photodamage that can ultimately lead to skin cancer [51], [52]. Notably, the system of Fitzpatrick Skin Phototypes is not based on skin color or race but on the report of an individual human subject regarding his or her skin responses to exposure to sunlight, including erythema [53].

\section{The Role of Phytochemicals in Photoprotection} $\nabla$

In order to cope with the consequences of exposure to damaging agents, including UV radiation, both plants and animals are equipped with various protective small molecules and enzymatic defenses such as the UV-absorbing melanin, carotenoids, and retinoids; the antioxidants ascorbic acid and tocopherol; and the proteins involved in DNA repair, in detoxification of reactive oxygen and nitrogen species, and in processing and disposition of damaged cellular components. Small molecules from plants are excellent candidates for the development of exogenous multifunctional protective agents for the skin of animals and humans due to their multiple activities that counteract the damaging effects of UV radiation ( $\bullet$ Fig. 1). In a comprehensive manuscript, Sies and Stahl have described the use of a number of nutrients as systemic photoprotective dietary agents [54].

This review summarizes the most prominent examples of phytochemicals that have been investigated for their ability to protect the skin of mice and humans from the damaging effects of UV radiation. They belong to several different classes of secondary metabolites: alkaloids, flavonoids, carotenoids, isothiocyanates, and "other" ( $\bullet$ Fig. 2). Their protective effects are versatile and include (i) direct absorption (light filtering); (ii) inhibition of chronic inflammation; (iii) modulation of immunosuppression, (iv) induction of apoptosis; (v) direct antioxidant (i. e., scavenging of reactive oxygen and nitrogen intermediates); and (vi) indirect antioxidant (i.e., induction of intrinsic cytoprotective responses through the Keap1/Nrf2/ARE system that leads to detoxification of various oxidants and electrophiles). Achievement of protection by induction of cytoprotective proteins is unique in that it is not dependent on the presence of the protective agent at the time point of exposure to UV radiation. It can be envisioned that such induction could protect against photodamage and photocarcinogenesis in many ways by (i) providing more direct antioxidants (e.g., bilirubin and CO through induction of heme oxygenase- 1 and glutathione through induction of $\gamma$-glutamate cysteine ligase); (ii) stimulating glutathione regeneration through induction of glutathione reductase and thioredoxin reductase; (iii) increasing the levels of enzymes that detoxify oxidants and electrophiles [e.g., catalase, superoxide dismutase, glutathione peroxidase, glutathione transferases, $\mathrm{NAD}(\mathrm{P}) \mathrm{H}$ :quinone oxidoreductase 1]; (iv) enhancing the export of detoxification products via the multidrug response transporters; (v) inhibiting cytokine-mediated inflammation via induction of leukotriene $\mathrm{B}_{4}$ reductase; (vi) reducing iron overload and subsequent oxidative stress by elevating ferritin; and (vii) recognizing, repairing, and removing damaged proteins. Importantly, the protective effects of activation of the intrinsic enzymatic defenses are multiple, long-lasting (several days), and unlikely to evoke sensitization (e.g., pro-oxidation) or interference with the biosynthesis of vitamin D.

\section{Alkaloids \\ $\nabla$}

The alkaloids are an extraordinary diverse group of compounds that are related only by the presence of a nitrogen atom in a heterocyclic ring, are synthesized from amino acids, and play important roles in plant defense against herbivores and pathogens [55]. The most extensively investigated alkaloid with respect to protection against photodamage and photocarcinogenesis is caffeine. In the 1970 s Zajdela and Latajet described the striking re- 


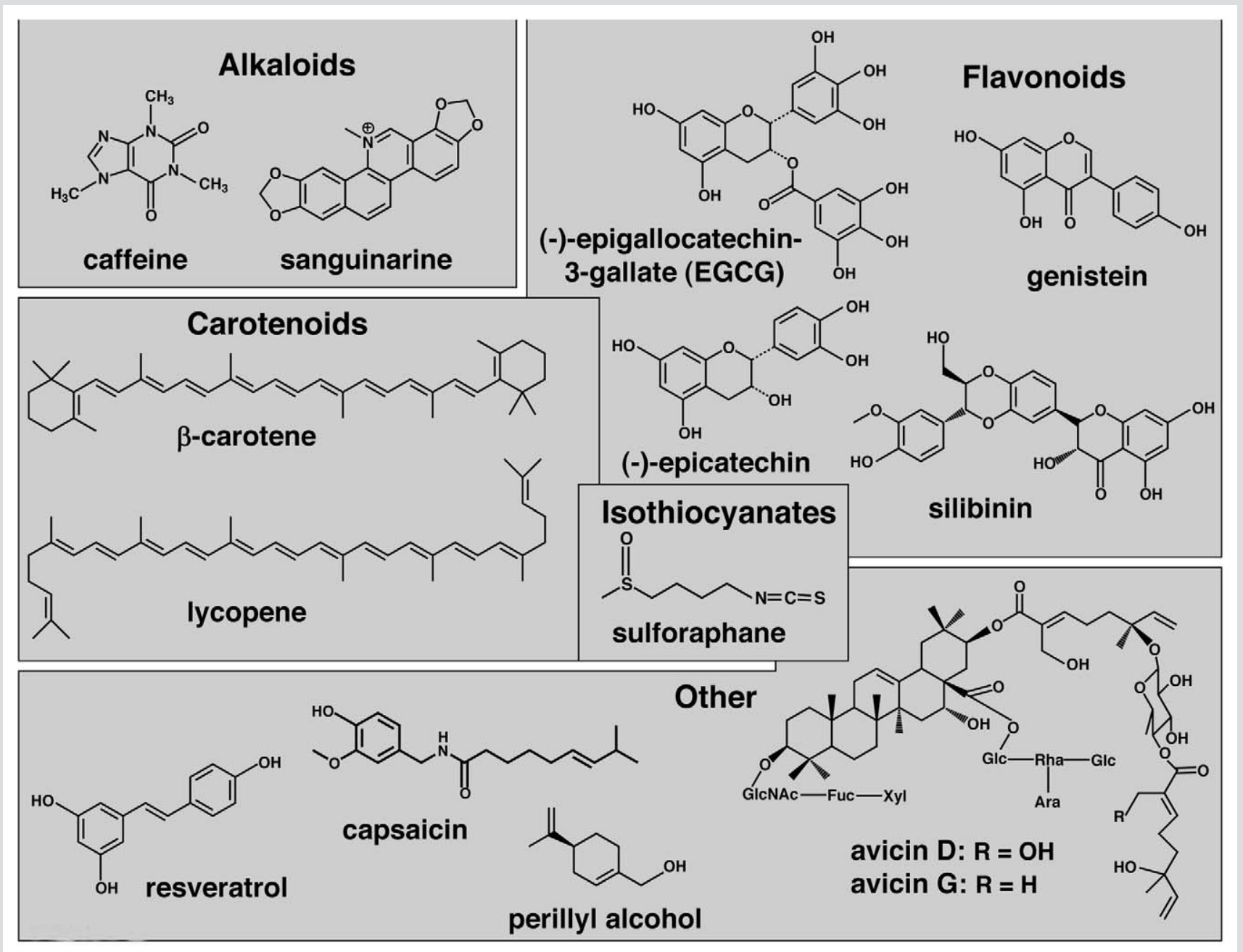

Fig. 2 Examples of phytochemicals that protect against damage by UV radiation.

duction of skin tumor formation by topical caffeine in UV-irradiated Swiss mice [56], [57]. A few years later, Bowden and Fussenig showed a correlation between the synergistic cytotoxic effects of caffeine and UV radiation and inhibition of DNA elongation in an immortalized epidermal cell line and showed that mouse primary keratinocytes have a post-replication DNA repair mechanism that is inhibited by caffeine [58], [59]. The extensive studies of Conney and his colleagues on the chemoprotective properties of tea in SKH-1 hairless mice that were rendered high-risk for skin cancer development by prior chronic exposure to low doses of UVB radiation demonstrated that decaffeinated beverages had little protective effect, whereas adding caffeine back restored protection [60]. Oral administration of caffeine enhanced the rate and extent of disappearance of mutant p53-positive patches, which represent early cellular markers of the beginning of tumor formation [61]. Furthermore, tumor multiplicity was reduced and this correlated with a decrease in the size of parametrial fat pads and in the thickness of the subcutaneous fat layer [62]. Detailed mechanistic studies revealed that the UVBinduced increase in epidermal phospho-Chk1 (Ser-345) was inhibited, whereas the level of epidermal cyclin B1 and the number of mitotic cells with cyclin B1 was increased, suggesting that the $\mathrm{G}_{2} / \mathrm{M}$ checkpoint was abrogated, causing lethal mitosis and apoptosis [63]. The stimulating effect on UV radiation-in- duced apoptosis was even greater and larger than additive when mice consuming caffeine $(0.1 \mathrm{mg} / \mathrm{mL}$ in the drinking water) were also allowed to exercise voluntarily [64], [65]. Although no human studies on photoprotection by caffeine have been reported, it is noteworthy that the plasma levels of caffeine in these animals are comparable to the plasma levels of caffeine in humans consuming $1-2$ cups of coffee per day [65].

In the same model system, topical application of caffeine also led to a decrease in tumor incidence, multiplicity, and volume [66]. Caffeine increased the number of UVB-induced apoptotic cells [67], [68] and stimulated apoptosis in UVB-induced focal hyperplasia and tumors in tumor-bearing mice [67]. In addition, caffeine had a light-filtering (sunscreen) effect, and caffeine sodium benzoate was more active than caffeine as a sunscreen and as an activator of UVB-induced apoptosis [69]. Interestingly, topical application of caffeine selectively stimulated apoptosis in the tumors, but not in the surrounding normal epidermis [70], and facilitated the elimination of epidermal cells carrying mutant p53 [67]. Very recently, 50 caffeine analogues were screened for their ability to inhibit epidermal growth factor (EGF)-induced malignant transformation of mouse epidermal JB6 cells, and 1-ethyl3-hexylxanthine (xanthine 70) was identified as the most potent compound [71]. The same compound also was found to inhibit 12-O-tetradecanoylphorbol 13-acetate (TPA)- and H-Ras-in- 
duced transformation and was suggested as a candidate for a potential chemoprotective agent.

Several epidemiological studies complement and support the experimental evidence for the protective effects of caffeine against cancer [72], [73], [74], [75], [76], [77], [78]. Thus, a population-based case-control study evaluated how tea consumption patterns of an older population in southeastern Arizona $(n=450)$ related to history of squamous cell carcinoma of the skin [76]. It was found that consumers of hot tea had significantly lower risk than non-consumers (OR: 0.33 ; $95 \% \mathrm{CI}: 0.12-0.87$ ) and that tea strength, brewing time, and temperature have a profound influence on the protective effect. Another population-based casecontrol study in New Hampshire ( $n=2181$ ) showed that regular tea consumption was associated with a significantly lower risk of squamous cell carcinoma of the skin (OR: $0.70 ; 95 \% \mathrm{CI}$ : $0.53-0.92$ ), especially among long-term drinkers and those consuming two or more cups a day [77]. The same study also found a weaker association between regular tea consumption and reduced risk of basal cell carcinoma of the skin. A cross-sectional analysis of subjects enrolled in the Women's Health Initiative Observational Study $(n=93,676)$ revealed that, compared with non-consumers, Caucasian women drinking regularly caffeinated (but not decaffeinated) coffee had a 10.8\% lower prevalence of non-melanoma skin cancer and that the prevalence was further reduced by $30 \%$ for those consuming six or more cups per day [78].

Sanguinarine, a benzophenanthridine alkaloid from the root of Sanguinaria canadensis, has antioxidant [79] and anti-inflammatory [80] activities and protects $\mathrm{HaCaT}$ cells from the damaging effects of UV radiation [81]. Furthermore, in SKH-1 hairless mice, topical application of sanguinarine either $30 \mathrm{~min}$ before or 5 min after exposure to UV radiation led to a reduction in edema, hyperplasia, and infiltration of inflammatory cells and to suppression of the activation of ornithine decarboxylase (ODC), proliferating cell nuclear antigen (PCNA), and Kiel antigen-67 [82].

\section{Flavonoids}

$\nabla$

Flavonoids are ubiquitously distributed in many edible plants and are widely consumed by humans as part of a plant-rich diet as well as being present in red wine, cocoa, and tea [83]. Flavonoids absorb UV light, have direct and indirect (by induction of cytoprotective proteins) antioxidant activities [84], [85], and are able to modulate signaling pathways [86], [87]. (-)-Epigallocatechin 3-gallate from green tea (Camellia sinensis) is the most extensively studied flavonoid in terms of protection against UV radiation-induced photodamage and photocarcinogenesis. It inhibits UVB-induced AP-1 activation in cultured human keratinocytes [88], [89] as well as in the epidermis of topically treated transgenic reporter mice expressing luciferase under the control of two AP-1 response elements [88]. In the human keratinocyte cell line HaCaT, EGCG inhibits the UVB-induced expression of c-fos and the activation of $\mathrm{p} 38$ mitogen-activated protein kinase [89].

(-)-Epigallocatechin 3-gallate [66], [90] and green tea polyphenol fraction [91] effectively prevent carcinogenesis in UVB radiation-treated mice when administered either in the diet or topically. Reduced expression of the matrix metalloproteases MMP2 and MMP-9 and of vascular endothelial growth factor, enhanced expression of the tissue inhibitor of MMP, and increased numbers of $\mathrm{CD}^{+} \mathrm{T}$ cells were observed in tumors from UV-irradiated mice consuming green tea polyphenols compared with control animals, strongly suggesting that the treatment affects several processes involved in tumor development, including angiogenesis and inflammation [91]. In addition, topical application of EGCG protects against UV radiation-induced immunosuppression, and this protection correlates with inhibition of macrophage and neutrophil infiltration, lower levels of IL-10 in irradiated mouse skin, and a marked increase in levels of IL-12 [92], [93], [94], [95], which antagonizes UV radiation-induced immunosuppression and induces nucleotide-excision repair (see above) [45], [96], [97]. Very recently it was shown that exposure to green tea polyphenols protected against UV radiationmediated DNA damage and apoptosis in human keratinocytes and human skin equivalents [98]. This protection correlated with induction of IL-12 secretion and was almost completely reversed by addition of an anti-IL-12 antibody, strongly implicating IL-12 as an important mediator of the protective effects of green tea polyphenols.

Topical application of green tea polyphenol fraction inhibited UV radiation-evoked erythema and the formation of DNA pyrimidine dimers in human skin [99]. Pretreatment of small areas of photoprotected buttock skin of six human subjects with EGCG $\left(1 \mathrm{mg} / \mathrm{cm}^{2}\right)$ before a single exposure to $4 \times$ the minimal erythema dose (MED) of UVB radiation prevented erythema and associated inflammation, as well as generation of hydrogen peroxide and nitric oxide, and restored the UV-induced depletion of glutathione and glutathione peroxidase [99].

Yang and his colleagues undertook a detailed pharmacokinetic study in eight healthy human subjects after a single oral dose of green tea or EGCG (2 mg/kg) [100]. The dose of green tea $(20 \mathrm{mg}$ tea solids $/ \mathrm{kg}$ ) corresponds to $195 \mathrm{mg}$ (-)-epigallocatechin gallate, $154 \mathrm{mg}$ (-)-epigallocatechin, and $45 \mathrm{mg}$ (-)-epicatechin for an individual with a body weight of $70 \mathrm{~kg}$. Only a small percentage of the orally administered catechins was detected in blood, with a mean peak plasma EGCG concentration of $0.17 \mu \mathrm{M}$. In plasma, most of the EGCG was in free form, whereas (-)-epigallocatechin and (-)-epicatechin were conjugated. More than $90 \%$ of the total urinary (-)-epigallocatechin and (-)-epicatechin, both in conjugated form, was excreted within $8 \mathrm{~h}$. In addition, 4'-Omethyl-(-)-epigallocatechin as well as two ring-fission metabolites, (-)-5-(3', $4^{\prime}, 5^{\prime}$-trihydroxyphenyl)- $\gamma$-valerolactone and (-)5 -(3', $4^{\prime}$-dihydroxyphenyl)-valerolactone, were detected in both urine and plasma. Substantial interindividual variations were noted, possibly due to differences in the intestinal microflora affecting the biotransformation of catechins.

In a pharmacokinetic and safety study of green tea polyphenols, groups of eight healthy human subjects received for a period of four weeks one of five treatments: 800 mg EGCG once a day, $400 \mathrm{mg}$ EGCG twice a day, $800 \mathrm{mg}$ EGCG within a defined decaffeinated green tea polyphenol mixture (Polyphenol E) once a day, $400 \mathrm{mg}$ EGCG as Polyphenol E twice a day, or a placebo once a day [101]. On average, there was $a>60 \%$ increase in the systemic availability of free EGCG after chronic green tea polyphenol administration at the high $(800 \mathrm{mg})$ daily bolus dose, whereas there were no significant changes in the pharmacokinetics of EGCG after repeated treatment of $400 \mathrm{mg}$ twice daily. There were no significant changes in blood counts and blood chemistry and no significant adverse events at any of the dosing regimens, indicating no concerns regarding safety and tolerance at these dosing regimens (equivalent to 16 Japanese-style cups of green tea per day). In addition, skin erythema was evaluated, 
and the dose of UV radiation causing just perceptible erythema (minimal erythema dose, MED) was determined at baseline and after four weeks of green tea polyphenol intake. No change in MED in response to solar-simulating UV radiation was observed, but, interestingly, subjects reported that they experienced lessintensive sunburn reactions after receiving the green tea polyphenol treatment. It is thus possible that there were subtle changes in skin photosensitivity without an impact on the MED. Other reasons for the apparent lack of change in MED could be that the local concentration of EGCG in skin after oral intake was insufficient to provide protection or that protection could have been achieved by a longer duration of treatment, as in the case of flavanol cocoa powder or carotenoid intake (see below). Much longer dietary intervention with a cocoa beverage rich in flavanols resulted in a decrease in sensitivity to UV radiation as determined by the degree of erythema following exposure to $1.25 \times$ MED of radiation from a solar light simulator [102]. In this study, two groups of women consumed either a high-flavanol (326 mg/day, containing $61 \mathrm{mg}$ epicatechin and $20 \mathrm{mg}$ catechin) or low-flavanol (27 mg/day, containing $6.6 \mathrm{mg}$ epicatechin and $1.2 \mathrm{mg}$ catechin) cocoa powder dissolved in $100 \mathrm{~mL}$ water for 12 weeks. Whereas there was no change in erythema development in the low-flavanol group compared with baseline, there was an improvement in skin condition and a significant reduction in erythema in the high-flavanol group, by $15 \%$ at 6 weeks and by $25 \%$ at 12 weeks of treatment.

Genistein, an isoflavone from soybean (Glycine max), is a potent antioxidant, an inhibitor of protein tyrosine kinase, and a phytoestrogen [103]. Prior exposure to genistein prevents the UV radiation-dependent expression of cyclooxygenase-2 (COX-2) [104], the increase in prostaglandin E2 (PGE2) synthesis [105], the activation of AP-1 [106], and the activation of signal transducer and activator of transcription-1 (STAT1) [107] in cultures of human keratinocytes. Topical application of genistein to hairless mice after exposure to solar-simulated UV radiation reduced the inflammatory edema reaction and the suppression of contact hypersensitivity [108]. When applied topically prior to UV radiation, genistein protected against photodamage in hairless mice [103], [109] and human reconstituted skin [110] and inhibited tumor development in hairless mice that were chronically exposed to UV radiation [103]. Interestingly, topical application of genistein $1 \mathrm{~h}$ or $4 \mathrm{~h}$ after UV exposure was also protective [109]. Reductions in erythema (quantified by reflectance spectroscopy) and discomfort in the skin of human volunteers were observed at sites to which genistein was applied $1 \mathrm{~h}$ before exposure to UV radiation [103].

Pycnogenol, a standardized extract of the bark of the French maritime pine (Pinus maritima), contains a number of phenolic and polyphenolic flavonoids, including monomeric procyanidins (catechin, epicatechin, and taxifolin) as well as oligomeric procyanidins of various chain lengths and binding patterns [111]. The extract exhibits potent direct and indirect (through activation of glutathione biosynthesis and antioxidant enzymes) antioxidant and anti-inflammatory activities [112], [113], [114]. Topical applications of pycnogenol immediately after irradiation significantly reduced inflammation, immunosuppression, and tumor development (time of appearance of the first tumor and number of tumors per mouse) in hairless mice that were chronically exposed to solar-simulated UV radiation [115].

Silibinin, a flavonolignan from the milk thistle (Silybum marianum), has also been shown to modulate a number of acute and chronic events involved in the photocarcinogenesis of the skin. Thus, it protects against UV radiation-induced DNA damage, enhances repair mechanisms, activates p53, induces cell cycle arrest, and inhibits cell proliferation and inflammation [116]. In $\mathrm{C} 3 \mathrm{H} / \mathrm{HeN}$ mice, inhibition of both local and systemic UV radiation-induced immunosuppression was demonstrated by topical application of silibinin, and this correlated with a reduction in the levels of UV radiation-mediated secretion of the immunosuppressive cytokine IL-10 [117]. Recently it was shown that silibinin administered either topically or in the diet to SKH-1 hairless mice chronically exposed to low doses of UV radiation delayed tumor appearance and reduced tumor multiplicity and volume. This protection was correlated with inhibition of markers of inflammation and angiogenesis, for example, reduced activation of NF $\kappa$ B and STAT3 and levels of inducible nitric oxide synthase (iNOS), cyclooxygenase-2 (COX-2), hypoxia-inducible factor $1 \alpha$ (HIF-1 $\alpha)$, and vascular endothelia growth factor (VEGF) [118].

\section{Carotenoids}

$\nabla$

Due to their extended conjugation systems, carotenoids and xanthophylls (oxocarotenoids) are very efficient scavengers of singlet oxygen and, under low oxygen tension, peroxyl radicals. They quench singlet oxygen in a reaction that involves transfer of excitation energy from ${ }^{1} \mathrm{O}_{2}$ to the carotenoid, resulting in ground-state $\mathrm{O}_{2}$ and dissipation of energy between the excited state carotenoid and the surrounding solvent to finally yield thermal energy and restore the ground-state carotenoid [6], [119]. However, under certain experimental conditions, they also can act as pro-oxidants [119]. In plants, xanthophylls facilitate the de-excitation of singlet excited chlorophyll, thus preventing energy transfer to oxygen and the subsequent formation of singlet oxygen, the overproduction of which could lead to degradation of key photosynthetic proteins and even cell death [120], [121]. In addition, carotenoids can scavenge singlet oxygen and triplet chlorophyll and inhibit lipid peroxidation [120], [121].

Intervention studies in humans with carotenoid-rich diets have shown photoprotection of the skin as measured by decreased sensitivity to UV radiation-induced erythema [6], [54], [122], [123], [124], [125]. Importantly, in these studies erythema was evaluated objectively by measuring the skin color before and 24 hours after irradiation using reflectance spectroscopy. Thus, dietary intake of tomato paste ( $40 \mathrm{~g} /$ day, equivalent to $16 \mathrm{mg}$ lycopene/day) over a period of 10 weeks led to a $40 \%$ reduction in skin erythema development induced by exposure to solar-simulating UV radiation [124]. Similarly, erythema development was diminished in subjects whose diets were supplemented with $\beta$ carotene ( $24 \mathrm{mg} /$ day) or a carotenoid mixture consisting of $\beta$ carotene, lutein, and lycopene ( $8 \mathrm{mg}$ each/day) for 12 weeks [125]. Protection correlated with an increase in the carotenoid levels in skin and serum. Interestingly, rather long treatment periods (a minimum of 10 weeks) were required to achieve photoprotection. It should be pointed out that the protective properties of carotenoids are probably at least two-fold, consisting of (i) their potent antioxidant activity and (ii) their ability to induce cellular protective responses. Thus, dietary carotenoids and their metabolites induce phase 2 cytoprotective enzymes [126], [127] and share with all other classes of phase 2 inducers a common chemical property, the ability to react with sulfhydryl groups [126]. 


\section{Isothiocyanates}

$\nabla$

In many ways, the isothiocyanates are unique phytochemicals. Although they are derived from cruciferous plants, the intact plants do not contain isothiocyanates but their glucosinolate precursors. Glucosinolates are $S$ - $\beta$-thioglucoside $N$-hydroxysulfates with more than 120 unique side chains derived from common amino acids [128], [129], [130]. In the same plant, but localized in different cells, are $\beta$-thioglucosidase enzymes known as myrosinases (EC 3.2.3.1). Thus, the flower stalk of Arabidopsis thaliana contains extraordinarily high concentrations of glucosinolates (> $100 \mathrm{mM}$ ) localized in specialized S (sulfur-rich) cells between the phloem and the endodermis, whereas myrosinase resides in the adjacent phloem parenchyma cells [131]. Thus, the only time when enzyme and substrate come into contact is when the plant tissue is damaged, such as during injury or chewing. The encounter results in hydrolysis of the glucosinolates: glucose and sulfate are liberated and unstable aglucones are formed, which then spontaneously rearrange to form isothiocyanates, thiocyanates, nitriles, epithionitriles, or oxazolidinethiones. At neutral $\mathrm{pH}$ and upon inactivation of a protein factor, for example, the epithiospecifier protein, the products are principally isothiocyanates [129], [132]. It should be pointed out that nearly all of the biological activities of glucosinolates (with the exception of indole glucosinolate), in both plants and animals, are attributable to their cognate isothiocyanate hydrolytic products.

In humans, isothiocyanates are metabolized by the mercapturic acid pathway [133], [134]. This involves initial conjugation with glutathione (catalyzed by glutathione transferases) and the sequential catalytic activities of $\gamma$-glutamyltransferase $(\gamma$-GT), cysteinylglycinase (CGase), and $\mathrm{N}$-acetyltransferase (AT) to ultimately form $\mathrm{N}$-acetylcysteine conjugates (mercapturic acids). Isothiocyanates and all of their glutathione-derived conjugates, collectively known as dithiocarbamates, are detected by the cyclocondensation reaction with 1,2-benzenedithiol [135], [136]. Talalay and his colleagues [137] conducted an inpatient, randomized, placebo-controlled, double-blind clinical phase 1 study of the safety, tolerance, and pharmacokinetics of broccoli sprout extracts containing either glucosinolates (principally glucoraphanin) or isothiocyanates (principally sulforaphane). Examination of 32 types of hematology or chemistry tests that were done before, during, and after the treatment period, including indicators of liver (transaminases) and thyroid (TSH, T3, and T4) function, revealed no evidence of systematic, clinically significant adverse events that could be attributed to ingestion of the sprout extracts. In this study, there were three cohorts, each comprising three treated and one placebo recipient. After a 5day acclimatization period, the volunteers received the extracts orally at 8-h intervals for 7 days (a total of 21 doses). The individual doses for each of the three cohorts were (i) $25 \mu \mathrm{mol}$ of glucosinolates, or a total of $75 \mu \mathrm{mol}$ per day per subject; (ii) $100 \mu \mathrm{mol}$ of glucosinolates, or a total of $300 \mu \mathrm{mol}$ per day per subject; and (iii) $25 \mu \mathrm{mol}$ of isothiocyanates, or a total of $75 \mu \mathrm{mol}$ per day per subject. The subjects were monitored throughout the intervention period and for three days after the last treatment. The mean cumulative excretion of dithiocarbamate metabolites as a fraction of dose was $17.8 \pm 8.6 \%$ ( \pm S.D.) and $19.6 \pm 11.7 \%$ ( \pm S.D.) for the low- and the high-glucosinolate dose-receiving cohorts, respectively, and the interindividual variation was high. In contrast, for the isothiocyanate dose-receiving cohort, the mean cumulative excretion of dithiocarbamate metabolites as a fraction of dose was much higher $(70.6 \pm 2.0 \%)$ and much more consistent among individuals.

The isothiocyanate sulforaphane was isolated from extracts of broccoli (Brassica oleracea) as the principal inducer in a bioassay screening system for identification of inducers of cytoprotective (phase 2) enzymes [138], [139]. Unlike most of the previously discussed phytochemicals, sulforaphane does not absorb light above $290 \mathrm{~nm}$ and does not have direct antioxidant activity. Due to its ability to potently induce cytoprotective (phase 2) enzymes through the Keap1/Nrf2/ARE system, including many enzymes related to glutathione and concerned with detoxification of oxidants and electrophiles [140], [141], [142], [143], [144], sulforaphane functions as an indirect antioxidant [145]. Sulforaphane activates the Keap1/Nrf2/ARE pathway by chemically modifying highly reactive cysteine residues of Keap1, the cellular sensor for phase 2 inducers [143]. As a consequence, Keap1 loses its ability to target transcription factor Nrf2 for ubiquitination and proteasomal degradation, resulting in its stabilization and nuclear translocation, where (in a heterodimeric combination with a small Maf protein) it binds to the antioxidant response element (ARE) and activates transcription of phase $2 \mathrm{cy}-$ toprotective genes ( $\mathbf{F i g . 3}$ ).

In addition to being a potent activator of the Keap1/Nrf2/ARE pathway, sulforaphane inhibits proinflammatory responses (i.e., lipopolysaccharide- and interferon- $\gamma$-mediated elevation of inducible nitric oxide synthase [iNOS] and cyclooxygenase 2 [COX-2]) at concentrations similar to those at which it induces cytoprotective responses [146]. Intraperitoneal injections of sulforaphane stimulate both humoral- and cell-mediated immunity in mice [147]. Furthermore, oral administration of sulforaphane (9 $\mu$ mol per mouse per day for 11 days) reversed age-associated decreases in contact hypersensitivity and $\mathrm{T}_{\mathrm{H}} 1$ immunity through Nrf2-mediated enhanced expression of cytoprotective enzymes and glutathione biosynthesis [148]. The authors concluded that sulforaphane stimulates $\mathrm{T}_{\mathrm{H}} 1$ immunity by restoring the redox equilibrium.

Topical daily applications of a standardized broccoli sprout extract (delivering $\sim 100 \mathrm{nmol} / \mathrm{cm}^{2}$ sulforaphane) to high-risk SKH-1 hairless mice leads to $\sim 50 \%$ reduction in tumor incidence, multiplicity, and volume [146]. This protective effect correlates with induction of the cytoprotective response in the skin of the animals. Importantly, treatment with either pure sulforaphane or broccoli sprout extracts containing an equivalent amount of sulforaphane has quantitatively equivalent effects on the induction of NQO1, a representative marker cytoprotective enzyme, and on the inhibition of UV radiation-dependent edema and inflammation in the skin [149]. When the enzyme activity of NQO1 was determined in 3-mm skin punch biopsies of healthy human volunteers after application of a single dose of broccoli sprout extract to small circular $(1 \mathrm{~cm}$ in diameter) areas of the skin, we found that despite large differences in basal activity levels among individuals, NQO1 was increased by approximately $\sim 2$-fold $24 \mathrm{~h}$ after application of an extract containing $100 \mathrm{nmol}$ of sulforaphane [150]. Three repeated applications (at 24-h intervals) of broccoli sprout extract containing a lower dose $(50 \mathrm{nmol})$ of sulforaphane led to even greater elevations $(\sim 2.5-$ fold), and when this dose was tripled, induction reached $\sim 4.5$ fold. Notably, induction was long-lasting, as the NQO1 activity remained higher than that of the placebo-treated sites even when the biopsies were obtained $72 \mathrm{~h}$ after the application of a single dose of the extract. This finding demonstrates that induction of the phase 2 response is highly efficient in both magnitude 

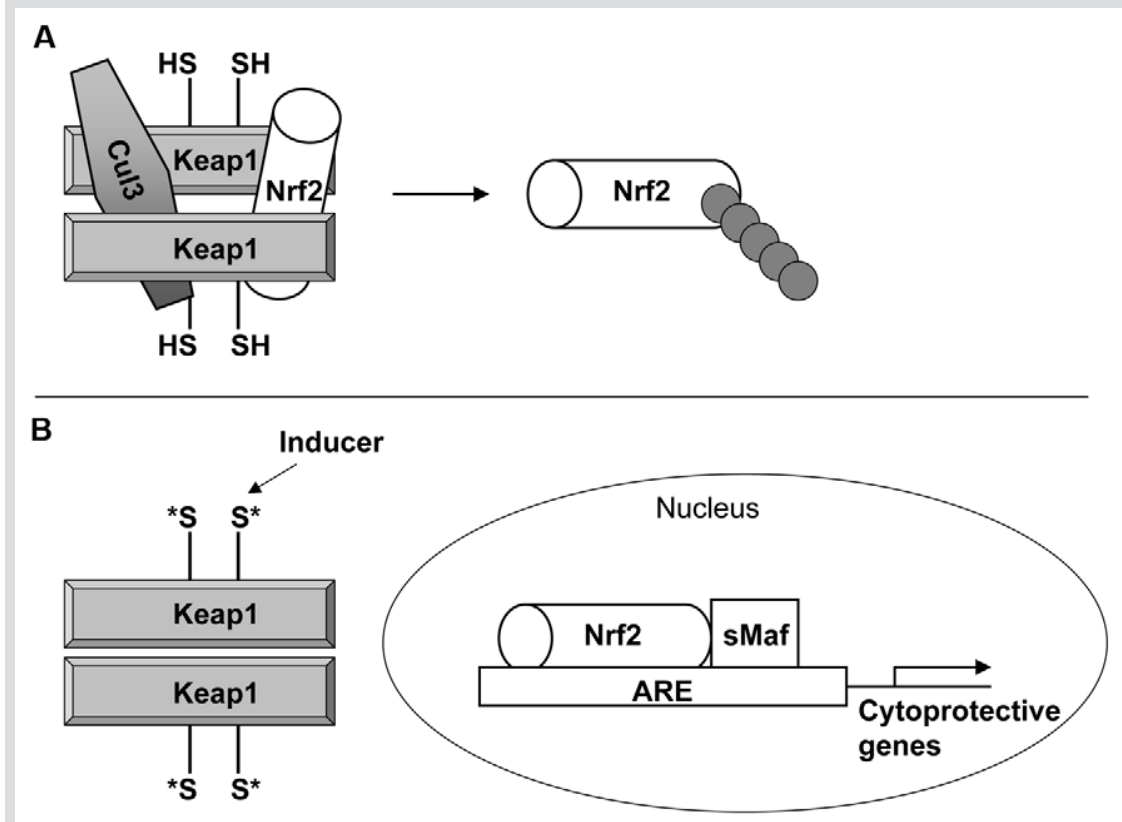

Fig. 3 Mechanism of induction of phase 2 cytoprotective proteins. (A) Under basal conditions the protein sensor for inducers, Keap1, binds and targets transcription factor $\mathrm{Nrf2}$ for ubiquitination and proteasomal degradation via association with the Cullin 3 (Cul3)-based E3 ubiquitin ligase. (B) Inducers react and chemically modify specific reactive cysteine residues of Keap1, which consequently loses its ability to repress $\mathrm{Nrf2}$. This leads to increased stabilization of $\mathrm{Nrf2}$, its nuclear translocation, binding to the ARE (in combination with small Maf), and, ultimately, transcriptional activation of cytoprotective genes. $\mathrm{SH}$ : reduced cysteine; $\mathrm{S}^{*}$ : modified cysteine. and duration. Importantly, the protective effects are expected to follow similar kinetics.

Protection against photodamage in healthy human subjects was evaluated by measuring the susceptibility to erythema arising from narrow-band (311 nm) UVB radiation [149]. Six healthy human volunteers ( 3 males and 3 females) received on 3 consecutive days at $24 \mathrm{~h}$ intervals sulforaphane-containing broccoli sprout extract or vehicle ( $80 \%$ acetone) applied topically to small circular areas ( $2 \mathrm{~cm}$ in diameter) on their photoprotected back skin. Twenty-four hours after the last dose, these small areas of the skin were exposed to narrow-band ( $311 \mathrm{~nm}$ ) UVB radiation. Erythema development was objectively determined $24 \mathrm{~h}$ after irradiation using reflectance spectroscopy and was found to be reduced by $\sim 40 \%$ at sites that received sulforaphane-containing extract compared with vehicle-treated sites. Because sulforaphane does not absorb light above $290 \mathrm{~nm}$ and because its effects are due to enhancement of the synthesis of cytoprotective proteins and inhibition of inflammatory processes, the protection is radically distinct from that of sunscreens, in that it is comprehensive, long-lasting, catalytic, and unlikely to interfere with vitamin D biosynthesis. The development of such agents for protection against UV radiation is especially attractive, because the skin is the only site of vitamin D synthesis, which is essential for the regulation of basic processes such as growth, differentiation, and immunity as well as in protection against cancer and other diseases, including autoimmune and infectious diseases [151].

\section{Other Phytochemicals}

Capsaicin, the pungent ingredient of hot chili peppers, is an antiinflammatory and analgesic agent. Topical application of capsaicin to ICR mice suppressed phorbol ester-stimulated activation of NF- $\kappa \mathrm{B}$ and activator protein-1 (AP-1) [152], [153]. In addition, capsaicin diminishes UV radiation-induced immunosuppression in both mice and humans [154], [155], [156], [157]. Thus, young mice injected subcutaneously with capsaicin before the age of 4 weeks retained their contact hypersensitivity responses to picryl chloride following exposure to UV radiation [154]. Topical appli- cation of capsaicin 24 and 48 hours prior to irradiation reduced the UV radiation-dependent suppression of delayed-type hypersensitivity responses to tuberculin purified protein derivative erythema in healthy Mantoux-positive human volunteers [157]. Resveratrol, a stilbene found in grapes, red wine, and nuts, has a plethora of biological activities, and the evidence of its protective functions in many animal models of stress and disease is continuously growing [158]. Interestingly, UV irradiation of grapes has been shown to increase their resveratrol content substantially [159], [160]. In human keratinocytes, exposure to resveratrol inhibited UV radiation-mediated activation of NF- $\kappa \mathrm{B}$ [161] and improved cell survival [162]. In SKH-1 hairless mice, topical application of resveratrol reduced the UV radiation-dependent increase in skin thickness, edema, and inflammation [163], [164]. These effects were accompanied by a reduction in UVB-mediated lipid peroxidation and induction of cyclooxygenase-2 (COX-2) and ornithine decarboxylase (ODC). Furthermore, resveratrol suppressed tumor development in SKH-1 hairless mice that were chronically exposed to UV radiation [165]. The monoterpene perillyl alcohol inhibited the UV-inducible activation of AP-1 in cultures of human keratinocytes (HaCaT) and, following topical application, in the skin of transgenic reporter mice carrying luciferase under the control of two copies of the AP-1 response element (TRE) [166]. In the same study, topical applications of perillyl alcohol $(0.5 \mu \mathrm{mol}$ to each ear and $1 \mu \mathrm{mol}$ to the shaved back surface, three times per week for 18 weeks, immediately after UV radiation) significantly inhibited tumor development in BALB/c mice.

Due to the Michael acceptor functionalities in their side chains, the triterpenoid derivatives avicins, from the Australian desert tree Acacia victoriae, activate transcription factor Nrf2, induce cytoprotective genes, and protect against damage by UV radiation. Thus, topical daily applications of $0.4 \mathrm{mg}$ avicin extracts, 5 days a week for 10 weeks, to the skin of SKH-1 hairless mice before exposure to UV radiation decreased the generation of 8-hydroxy-2'-deoxyguanosine and mutations in p53, inhibited epidermal hyperplasia, enhanced apoptosis, and elevated the expression of NADPH:quinone oxidoreductase 1 and heme oxygenase-1, two representative cytoprotective proteins [167]. 
Plant oligosaccharins that can modulate growth, development, and gene expression and thus function as "non-traditional plant hormones" [168] also have been shown to have biological activities in mammalian systems. Thus, tamarind xyloglucans reduced the UV radiation-dependent increase in the levels of IL10 in irradiated keratinocytes and mouse skin, protected against suppression of delayed-type hypersensitivity responses [169], and have been suggested to be unique protectors against the immunosuppressive effects of UV radiation [170].

\section{Concluding Remarks}

$\nabla$

Various phytochemicals protect plants and animals against the damaging effects of UV radiation. They all invoke multiple protective mechanisms, in many ways representing a critical feature in the efforts to develop protective strategies against a carcinogen that exerts multiple damaging effects. The use of agents based on some of the phytochemicals that were discussed here and the identification of new and more potent analogues, in addition to common sunscreens, are areas of development that have the potential to reduce the risk of skin cancer.

\section{Acknowledgements}

$\nabla$

The author is grateful to Research Councils UK, the American Cancer Society (RSG-07-157-01-CNE and IRG 5800543), the Anonymous Trust, and the American Institute for Cancer Research for providing research funds.

\section{References}

1 Diffey $B$. Climate change, ozone depletion and the impact on ultraviolet exposure of human skin. Phys Med Biol 2004; 49: R1 - 11

2 de Gruijl FR, Longstreth J, Norval M, Cullen AP, Slaper H, Kripke ML et al. Health effects from stratospheric ozone depletion and interactions with climate change. Photochem Photobiol Sci 2003; 2: 16-28

3 Norval M, Cullen AP, de Gruijl FR, Longstreth J, Takizawa Y, Lucas RM et $a l$. The effects on human health from stratospheric ozone depletion and its interactions with climate change. Photochem Photobiol Sci 2007; 6: $232-51$

4 Diffey BL. Solar ultraviolet radiation effects on biological systems. Phys Med Biol 1991; 36: 299-328

5 Diffey BL. What is light. Photodermatol Photoimmunol Photomed 2002; $18: 68-74$

6 Sies H, Stahl W. Carotenoids and UV protection. Photochem Photobiol Sci 2004; 3: 749-52

7 Karran P, Attard N. Thiopurines in current medical practice: molecular mechanisms and contributions to therapy-related cancer. Nat Rev Cancer 2008; 8: 24-36

8 Mitchell D. Revisiting the photochemistry of solar UVA in human skin. Proc Natl Acad Sci USA 2006; 103: $13567-8$

9 Godar DE. UV doses worldwide. Photochem Photobiol 2005; 81: 736 49

10 Young $R W$. The family of sunlight-related eye diseases. Optom Vis Sci 1994; 71: $125-44$

11 Alam M, Ratner D. Cutaneous squamous-cell carcinoma. N Engl J Med 2001; 344: $975-83$

12 Diepgen TL, Mahler V. The epidemiology of skin cancer. Br J Dermatol 2002; 146 (Suppl 61): $1-6$

13 NIH publication No. $95-1564 ; 1995$

14 van Steeg $\mathrm{H}$, Kraemer $\mathrm{KH}$. Xeroderma pigmentosum and the role of UV-induced DNA damage in skin cancer. Mol Med Today 1999; 5: $86-94$

15 Setlow RB, Carrier WL. Pyrimidine dimers in ultraviolet-irradiated DNA's. J Mol Biol 1966; 17: $237-54$

16 Cadet J, Sage E, Douki T. Ultraviolet radiation-mediated damage to cellular DNA. Mutat Res 2005; 571: 3-17
17 Daya-Grosjean L, Sarasin A. UV-specific mutations of the human patched gene in basal cell carcinomas from normal individuals and xeroderma pigmentosum patients. Mutat Res 2000; 450: 93 -9

18 Daya-Grosjean L, Dumaz N, Sarasin A. The specificity of p53 mutation spectra in sunlight induced human cancers. J Photochem Photobiol B 1995; 28: $115-24$

19 Daya-Grosjean L, Robert C, Drougard C, Suarez H, Sarasin A. High mutation frequency in ras genes of skin tumors isolated from DNA repair deficient xeroderma pigmentosum patients. Cancer Res 1993; 53: $1625-9$

20 Ziegler A, Jonason AS, Leffell DJ, Simon JA, Sharma HW, Kimmelman J et al. Sunburn and p53 in the onset of skin cancer. Nature 1994; 372: $773-6$

21 Williams C, Pontén F, Ahmadian A, Ren ZP, Ling G, Rollman $O$ et al. Clones of normal keratinocytes and a variety of simultaneously present epidermal neoplastic lesions contain a multitude of p53 gene mutations in a xeroderma pigmentosum patient. Cancer Res 1998; 58: 2449-55

$22 \mathrm{Au}$ V, Madison SA. Effects of singlet oxygen on the extracellular matrix protein collagen: oxidation of the collagen crosslink histidinohydroxylysinonorleucine and histidine. Arch Biochem Biophys 2000; 384: $133-42$

23 Mouret S, Baudouin C, Charveron M, Favier A, Cadet J, Douki T. Cyclobutane pyrimidine dimers are predominant DNA lesions in whole human skin exposed to UVA radiation. Proc Natl Acad Sci USA 2006; 103: $13765-70$

24 Nijhof JG, van Pelt C, Mulder AA, Mitchell DL, Mullenders LH, de Gruijl FR. Epidermal stem and progenitor cells in murine epidermis accumulate UV damage despite NER proficiency. Carcinogenesis 2007; 28: $792-$ 800

25 Nijhof JG, Mulder AM, Speksnijder EN, Hoogervorst EM, Mullenders LH, de Gruijl FR. Growth stimulation of UV-induced DNA damage retaining epidermal basal cells gives rise to clusters of p53 overexpressing cells. DNA Repair (Amst) 2007; 6: 1642-50

26 Melnikova VO, Ananthaswamy HN. Cellular and molecular events leading to the development of skin cancer. Mutat Res 2005; 571: 91 106

27 Klotz LO, Pellieux C, Briviba K, Pierlot C, Aubry JM, Sies H. Mitogen-activated protein kinase (p38-, JNK-, ERK-) activation pattern induced by extracellular and intracellular singlet oxygen and UVA. Eur J Biochem 1999; 260: 917 - 22

28 Silvers AL, Bachelor MA, Bowden GT. The role of JNK and p38 MAPK activities in UVA-induced signaling pathways leading to AP-1 activation and c-Fos expression. Neoplasia 2003; 5: 319-29

29 Bachelor MA, Bowden GT. UVA-mediated activation of signaling pathways involved in skin tumor promotion and progression. Semin Cancer Biol 2004; 14: 131 -8

30 Cooper SJ, Bowden GT. Ultraviolet B regulation of transcription factor families: roles of nuclear factor-kappa $\mathrm{B}(\mathrm{NF}-\kappa \mathrm{B})$ and activator protein-1 (AP-1) in UVB-induced skin carcinogenesis. Curr Cancer Drug Targets 2007; 7: $325-34$

31 Kripke ML. Immunological unresponsiveness induced by ultraviolet radiation. Immunol Rev 1984; 80: 87-102

32 Halliday GM. Inflammation, gene mutation and photoimmunosuppression in response to UVR-induced oxidative damage contributes to photocarcinogenesis. Mutat Res 2005; 571: $107-20$

33 Simon JC, Krutmann J, Elmets CA, Bergstresser PR, Cruz Jr. PD. Ultraviolet B-irradiated antigen-presenting cells display altered accessory signaling for T-cell activation: relevance to immune responses initiated in skin. J Invest Dermatol 1992; 98: 66S-9S

34 Vermeer M, Streilein JW. Ultraviolet B light-induced alterations in epidermal Langerhans cells are mediated in part by tumor necrosis factor-alpha. Photodermatol Photoimmunol Photomed 1990; 7: 258 - 65

35 Chung HT, Burnham DK, Robertson B, Roberts LK, Daynes RA. Involvement of prostaglandins in the immune alterations caused by the exposure of mice to ultraviolet radiation. J Immunol 1986; 137: 2478-84

36 Feldmeyer L, Keller M, Niklaus G, Hohl D, Werner S, Beer HD. The inflammasome mediates UVB-induced activation and secretion of interleukin- $1 \beta$ by keratinocytes. Curr Biol 2007; 17: $1140-5$

37 Schwarz T, Luger TA. Effect of UV irradiation on epidermal cell cytokine production. J Photochem Photobiol B 1989; 4: 1 - 13

38 Chung JH, Youn SH, Koh WS, Eun HC, Cho KH, Park KC et al. Ultraviolet B irradiation-enhanced interleukin (IL)-6 production and mRNA expression are mediated by IL- $1 \alpha$ in cultured human keratinocytes. J Invest Dermatol 1996; 106: 715-20 
39 Yano S, Banno T, Walsh R, Blumenberg M. Transcriptional responses of human epidermal keratinocytes to cytokine interleukin-1. J Cell Physiol 2008; 214: 1 - 13

40 Kondo S, Kono T, Sauder DN, McKenzie RC. IL-8 gene expression and production in human keratinocytes and their modulation by UVB. J Invest Dermatol 1993; 101: 690-4

41 Schwarz A, Schwarz T. Molecular determinants of UV-induced immunosuppression. Exp Dermatol 2002; 11 (Suppl 1): 9-12

42 Loser K, Apelt J, Voskort M, Mohaupt M, Balkow S, Schwarz T et al. IL-10 controls ultraviolet-induced carcinogenesis in mice. J Immunol 2007; 179: $365-71$

43 Schwarz A, Grabbe S, Aragane Y, Sandkuhl K, Riemann H, Luger TA et al. Interleukin-12 prevents ultraviolet B-induced local immunosuppression and overcomes UVB-induced tolerance. J Invest Dermatol 1996; 106: $1187-91$

44 Riemann H, Schwarz A, Grabbe S, Aragane Y, Luger TA, Wysocka M et al. Neutralization of IL-12 in vivo prevents induction of contact hypersensitivity and induces hapten-specific tolerance. J Immunol 1996; 156: $1799-803$

45 Schwarz A, Ständer S, Berneburg M, Böhm M, Kulms D, van Steeg H et al. Interleukin-12 suppresses ultraviolet radiation-induced apoptosis by inducing DNA repair. Nat Cell Biol 2002; 4: 26-31

46 Maeda A, Schneider SW, Kojima M, Beissert S, Schwarz T, Schwarz A. Enhanced photocarcinogenesis in interleukin-12-deficient mice. Cancer Res 2006; 66: $2962-9$

47 Andersen PH, Abrams K, Bjerring P, Maibach $H$. A time-correlation study of ultraviolet B-induced erythema measured by reflectance spectroscopy and laser Doppler flowmetry. Photodermatol Photoimmunol Photomed 1991; 8: 123 -8

48 Andersen PH, Abrams K, Maibach H. Ultraviolet B dose-dependent inflammation in humans: a reflectance spectroscopic and laser Doppler flowmetric study using topical pharmacologic antagonists on irradiated skin. Photodermatol Photoimmunol Photomed 1992; 9: 17-23

49 Andersen $P H$, Bjerring $P$. Spectral reflectance of human skin in vivo. Photodermatol Photoimmunol Photomed 1990; 7: 5-12

50 Wagner JK, Jovel C, Norton HL, Parra EJ, Shriver MD. Comparing quantitative measures of erythema, pigmentation and skin response using reflectometry. Pigment Cell Res 2002; 15: 379-84

51 O'Donovan P, Perrett CM, Zhang X, Montaner B, Xu YZ, Harwood CA et al. Azathioprine and UVA light generate mutagenic oxidative DNA damage. Science 2005; 309: $1871-4$

52 Young AR, Sheehan JM, Chadwick CA, Potten CS. Protection by ultraviolet $A$ and $B$ sunscreens against in situ dipyrimidine photolesions in human epidermis is comparable to protection against sunburn. J Invest Dermatol 2000; 115: $37-41$

53 Fitzpatrick TB. The validity and practicality of sun-reactive skin types through VI. Arch Dermatol 1988; 124: 869 - 71

54 Sies $H$, Stahl W. Nutritional protection against skin damage from sunlight. Annu Rev Nutr 2004; 24: 173 - 200

55 Ziegler J, Facchini PJ. Alkaloid biosynthesis: metabolism and trafficking. Annu Rev Plant Biol, in press;

56 Zajdela $F$, Latarjet $R$. Effect inhibiteurs de caffeine sur l'induction de cancers par les rayons ultraviolet chex la souris. C R Acad Sci Hebd Seances Acad Sci D. 1973; 277: 1073 - 6

57 Zajdela $F$, Latarjet $R$. Inhibition of skin carcinogenesis in vivo by caffeine and other agents. Natl Cancer Inst Monogr 1978; 50: 33 - 40

58 Bowden GT, Giesselbach B, Fusenig NE. Postreplication repair of DNA in ultraviolet light-irradiated normal and malignancy transformed mouse epidermal cell cultures. Cancer Res 1978; 38: 2709-18

59 Bowden GT, Fusenig NE. Caffeine inhibition of postreplication repair of UV-damaged DNA in mouse cells. Chem Biol Interact 1980; 33: 101 13

60 Lou YR, Lu YP, Xie JG, Huang MT, Conney AH. Effects of oral administration of tea, decaffeinated tea, and caffeine on the formation and growth of tumors in high-risk SKH-1 mice previously treated with ultraviolet B light. Nutr Cancer 1999; 33: 146-53

61 Lu YP, Lou YR, Liao J, Xie JG, Peng QY, Yang CS et al. Administration of green tea or caffeine enhances the disappearance of UVB-induced patches of mutant p53 positive epidermal cells in SKH-1 mice. Carcinogenesis 2005 ; 26 : $1465-72$

62 Lu YP, Lou YR, Lin Y, Shih WJ, Huang MT, Yang CS et al. Inhibitory effects of orally administered green tea, black tea, and caffeine on skin carcinogenesis in mice previously treated with ultraviolet B light (highrisk mice): relationship to decreased tissue fat. Cancer Res 2001; 61: $5002-9$
63 Lu YP, Lou YR, Peng QY, Xie JG, Nghiem P, Conney AH. Effect of caffeine on the ATR/Chk1 pathway in the epidermis of UVB-irradiated mice. Cancer Res 2008; 68: 2523 -9

64 Lu YP, Lou YR, Nolan B, Peng QY, Xie JG, Wagner GC et al. Stimulatory effect of voluntary exercise or fat removal (partial lipectomy) on apoptosis in the skin of UVB light-irradiated mice. Proc Natl Acad Sci USA 2006; 103: $16301-6$

65 Lu YP, Nolan B, Lou YR, Peng QY, Wagner GC, Conney AH. Voluntary exercise together with oral caffeine markedly stimulates UVB light-induced apoptosis and decreases tissue fat in SKH-1 mice. Proc Natl Acad Sci USA 2007; 104: 12 936 - 41

66 Lu YP, Lou YR, Xie JG, Peng QY, Liao J, Yang CS et al. Topical applications of caffeine or (-)-epigallocatechin gallate (EGCG) inhibit carcinogenesis and selectively increase apoptosis in UVB-induced skin tumors in mice. Proc Natl Acad Sci USA 2002; 99: 12455 - 60

67 Conney AH, Kramata P, Lou YR, Lu YP. Effect of caffeine on UVB-induced carcinogenesis, apoptosis, and the elimination of UVB-induced patches of p53 mutant epidermal cells in SKH-1 mice. Photochem Photobiol 2008; 84: $330-8$

68 Koo SW, Hirakawa S, Fujii S, Kawasumi M, Nghiem P. Protection from photodamage by topical application of caffeine after ultraviolet irradiation. Br J Dermatol 2007; 156: 957 - 64

69 Lu YP, Lou YR, Xie JG, Peng QY, Zhou S, Lin Y et al. Caffeine and caffeine sodium benzoate have a sunscreen effect, enhance UVB-induced apoptosis, and inhibit UVB-induced skin carcinogenesis in $\mathrm{SKH}-$ 1 mice. Carcinogenesis 2007; 28: 199 - 206

70 Conney AH, Zhou S, Lee MJ, Xie JG, Yang CS, Lou YR et al. Stimulatory effect of oral administration of tea, coffee or caffeine on UVB-induced apoptosis in the epidermis of SKH-1 mice. Toxicol Appl Pharmacol 2007; 224: 209-13

71 Rogozin EA, Lee KW, Kang NJ, Yu H, Nomura M, Miyamoto KI et al. Inhibitory effects of caffeine analogues on neoplastic transformation: structure-activity relationship. Carcinogenesis, in press;

72 Nkondjock A, Ghadirian P, Kotsopoulos J, Lubinski J, Lynch H, Kim-Sing C et al. Coffee consumption and breast cancer risk among BRCA1 and BRCA2 mutation carriers. Int J Cancer 2006; 118: $103-7$

73 Kurozawa Y, Ogimoto I, Shibata A, Nose T, Yoshimura T, Suzuki H et al. Coffee and risk of death from hepatocellular carcinoma in a large cohort study in Japan. Br J Cancer 2005; 93: 607-10

74 Gelatti U, Covolo L, Franceschini M, Pirali F, Tagger A, Ribero ML et al. Coffee consumption reduces the risk of hepatocellular carcinoma independently of its aetiology: a case-control study. J Hepatol 2005 42: $528-34$

75 Baker JA, McCann SE, Reid ME, Nowell S, Beehler GP, Moysich KB. Associations between black tea and coffee consumption and risk of lung cancer among current and former smokers. Nutr Cancer 2005; 52: 15-21

76 Hakim IA, Harris RB, Weisgerber UM. Tea intake and squamous cell carcinoma of the skin: influence of type of tea beverages. Cancer Epidemiol Biomarkers Prev 2000; 9: 727-31

77 Rees JR, Stukel TA, Perry AE, Zens MS, Spencer SK, Karagas MR. Tea consumption and basal cell and squamous cell skin cancer: results of a case-control study. J Am Acad Dermatol 2007; 56: 781 - 5

78 Abel EL, Hendrix SO, McNeeley SG, Johnson KC, Rosenberg CA, MossavarRahmani $Y$ et al. Daily coffee consumption and prevalence of nonmelanoma skin cancer in Caucasian women. Eur J Cancer Prev 2007; 16 : 446- 52

79 Mitscher LA, Park YH, Clark D, Clark III GW, Hammesfahr PD, Wu WN et al. Antimicrobial agents from higher plants. An investigation of Hunnemannia fumariaefolia pseudoalcoholates of sanguinarine and chelerythrine. Lloydia 1978; 41: 145 - 50

80 Lenfeld J, Kroutil M, Marsálek E, Slavík J, Preininger V, Simánek V. Antiinflammatory activity of quaternary benzophenanthridine alkaloids from Chelidonium majus. Planta Med 1981; 43: 161 - 5

81 Reagan-Shaw S, Breur J, Ahmad N. Enhancement of UVB radiationmediated apoptosis by sanguinarine in HaCaT human immortalized keratinocytes. Mol Cancer Ther 2006; 5: 418-29

82 Ahsan H, Reagan-Shaw S, Eggert DM, Tan TC, Afaq F, Mukhtar H et al. Protective effect of sanguinarine on ultraviolet B-mediated damages in SKH-1 hairless mouse skin: implications for prevention of skin cancer. Photochem Photobiol 2007; 83: 986 - 93

83 Ross JA, Kasum CM. Dietary flavonoids: bioavailability, metabolic effects, and safety. Annu Rev Nutr 2002; 22: 19 - 34

84 Dinkova-Kostova AT. Protection against cancer by plant phenylpropenoids: induction of mammalian anticarcinogenic enzymes. Mini Rev Med Chem 2002; 2: $595-610$ 
85 Dinkova-Kostova AT, Talalay P. Direct and indirect antioxidant properties of inducers of cytoprotective proteins. Mol Nutr Food Res, in press;

86 Williams RJ, Spencer JP, Rice-Evans C. Flavonoids: antioxidants or signalling molecules? Free Radic Biol Med 2004; 36: 838 - 49

87 Richelle $M$, Sabatier M, Steiling $H$, Williamson $G$. Skin bioavailability of dietary vitamin E, carotenoids, polyphenols, vitamin $\mathrm{C}$, zinc and selenium. Br J Nutr 2006; 96: 227 - 38

88 Barthelman M, Bair III WB, Stickland KK, Chen W, Timmermann BN, Valcic $S$ et al. (-)-Epigallocatechin-3-gallate inhibition of ultraviolet B-induced AP-1 activity. Carcinogenesis 1998; 19: 2201 - 4

89 Chen W, Dong Z, Valcic S, Timmermann BN, Bowden GT. Inhibition of ultraviolet B-induced c-fos gene expression and p38 mitogen-activated protein kinase activation by (-)-epigallocatechin gallate in a human keratinocyte cell line. Mol Carcinogen 1999; 24: 79-84

90 Mittal A, Piyathilake C, Hara Y, Katiyar SK. Exceptionally high protection of photocarcinogenesis by topical application of (-)-epigallocatechin-3-gallate in hydrophilic cream in SKH-1 hairless mouse model: relationship to inhibition of UVB-induced global DNA hypomethylation. Neoplasia 2003; 5: 555-65

91 Mantena SK, Roy AM, Katiyar SK. Epigallocatechin-3-gallate inhibits photocarcinogenesis through inhibition of angiogenic factors and activation of CD8+ T cells in tumors. Photochem Photobiol 2005; 81: $1174-9$

92 Katiyar SK, Challa A, McCormick TS, Cooper KD, Mukhtar H. Prevention of UVB-induced immunosuppression in mice by the green tea polyphenol (-)-epigallocatechin-3-gallate may be associated with alterations in IL10 and IL-12 production. Carcinogenesis 1999; 20: $2117-24$

93 Katiyar SK, Matsui MS, Elmets CA, Mukhtar H. Polyphenolic antioxidant (-)-epigallocatechin-3-gallate from green tea reduces UVB-induced inflammatory responses and infiltration of leukocytes in human skin. Photochem Photobiol 1999; 69: 148 - 53

94 Katiyar S, Elmets CA, Katiyar SK. Green tea and skin cancer: photoimmunology, angiogenesis and DNA repair. J Nutr Biochem 2007; 18: 287-96

95 Katiyar SK, Mukhtar H. Green tea polyphenol (-)-epigallocatechin-3gallate treatment to mouse skin prevents UVB-induced infiltration of leukocytes, depletion of antigen-presenting cells, and oxidative stress. J Leukoc Biol 2001; 69: 719-26

96 Meeran SM, Mantena SK, Katiyar SK. Prevention of ultraviolet radiation-induced immunosuppression by (-)-epigallocatechin-3-gallate in mice is mediated through interleukin 12-dependent DNA repair. Clin Cancer Res 2006; 12: 2272-80

97 Meeran SM, Mantena SK, Elmets CA, Katiyar SK. (-)-Epigallocatechin3-gallate prevents photocarcinogenesis in mice through interleukin12-dependent DNA repair. Cancer Res 2006; 66: 5512-20

98 Schwarz A, Maeda A, Gan D, Mammone T, Matsui MS, Schwarz T. Green tea phenol extracts reduce UVB-induced DNA damage in human cells via Interleukin-12. Photochem Photobiol 2008; 84: 350 - 5

99 Katiyar SK, Afaq F, Perez A, Mukhtar H. Green tea polyphenol (-)-epigallocatechin-3-gallate treatment of human skin inhibits ultraviolet radiation-induced oxidative stress. Carcinogenesis 2001; 22: 287 - 94

100 Lee MJ, Maliakal P, Chen L, Meng X, Bondoc FY, Prabhu S et al. Pharmacokinetics of tea catechins after ingestion of green tea and (-)-epigallocatechin-3-gallate by humans: formation of different metabolites and individual variability. Cancer Epidemiol Biomarkers Prev 2002; 11: 025 - 32

101 Chow HH, Cai Y, Hakim IA, Crowell JA, Shahi F, Brooks CA et al. Pharmacokinetics and safety of green tea polyphenols after multiple-dose administration of epigallocatechin gallate and polyphenon $\mathrm{E}$ in healthy individuals. Clin Cancer Res 2003; 9: 3312 - 9

102 Heinrich U, Neukam K, Tronnier H, Sies H, Stahl W. Long-term ingestion of high flavanol cocoa provides photoprotection against UV-induced erythema and improves skin condition in women. J Nutr 2006; 136: $1565-9$

103 Wei H, Saladi R, Lu Y, Wang Y, Palep SR, Moore J et al. Isoflavone genistein: photoprotection and clinical implications in dermatology. J Nutr 2003; 133: 3811S-9S

104 Isoherranen K, Punnonen K, Jansen C, Uotila P. Ultraviolet irradiation induces cyclooxygenase-2 expression in keratinocytes. Br J Dermatol 1999; 140: $1017-22$

105 Miller CC, Hale P, Pentland AP. Ultraviolet B injury increases prostaglandin synthesis through a tyrosine kinase-dependent pathway. Evidence for UVB-induced epidermal growth factor receptor activation. J Biol Chem 1994; 269: 3529-33
106 Isoherranen K, Westermarck J, Kähäri VM, Jansén C, Punnonen K. Differential regulation of the AP-1 family members by UV irradiation in vitro and in vivo. Cell Signal 1998; 10: $191-5$

107 Mazière C, Dantin F, Dubois F, Santus R, Mazière J. Biphasic effect of UVA radiation on STAT1 activity and tyrosine phosphorylation in cultured human keratinocytes. Free Radic Biol Med 2000; 28: $1430-7$

108 Widyarini S, Spinks N, Husband AJ, Reeve VE. Isoflavonoid compounds from red clover (Trifolium pratense) protect from inflammation and immune suppression induced by UV radiation. Photochem Photobiol 2001; 74: 465 - 70

109 Brand RM, Jendrzejewski JL. Topical treatment with (-)-epigallocatechin-3-gallate and genistein after a single UV exposure can reduce skin damage. J Dermatol Sci 2008; 50: 69-72

110 Moore JO, Wang Y, Stebbins WG, Gao D, Zhou X, Phelps R et al. Photoprotective effect of isoflavone genistein on ultraviolet B-induced pyrimidine dimer formation and PCNA expression in human reconstituted skin and its implications in dermatology and prevention of cutaneous carcinogenesis. Carcinogenesis 2006; 27: 1627 - 35

111 Rohdewald P. A review of the French maritime pine bark extract (Pycnogenol), a herbal medication with a diverse clinical pharmacology. Int J Clin Pharmacol Ther 2002; 40: 158-68

112 Cho KJ, Yun CH, Yoon DY, Cho YS, Rimbach G, Packer L et al. Effect of bioflavonoids extracted from the bark of Pinus maritima on proinflammatory cytokine interleukin-1 production in lipopolysaccharide-stimulated RAW 264.7. Toxicol Appl Pharmacol 2000; 168: 6471

113 Cho KJ, Yun CH, Packer L, Chung AS. Inhibition mechanisms of bioflavonoids extracted from the bark of Pinus maritima on the expression of proinflammatory cytokines. Ann N Y Acad Sci 2001; 928: 141 - 56

114 Packer L, Rimbach G, Virgili F. Antioxidant activity and biologic properties of a procyanidin-rich extract from pine (Pinus maritima) bark, pycnogenol. Free Radic Biol Med 1999; 27: 704- 24

115 Sime S, Reeve VE. Protection from inflammation, immunosuppression and carcinogenesis induced by UV radiation in mice by topical Pycnogenol. Photochem Photobiol 2004; 79: $193-8$

116 Singh RP, Agarwal R. Mechanisms and preclinical efficacy of silibinin in preventing skin cancer. Eur J Cancer 2005; 41: 1969-79

117 Meeran SM, Katiyar S, Elmets CA, Katiyar SK. Silymarin inhibits UV radiation-induced immunosuppression through augmentation of interleukin-12 in mice. Mol Cancer Ther 2006; 5: 1660-8

118 Gu M, Singh RP, Dhanalakshmi S, Agarwal C, Agarwal R. Silibinin inhibits inflammatory and angiogenic attributes in photocarcinogenesis in SKH-1 hairless mice. Cancer Res 2007; 67: 3483-91

119 El-Agamey A, Lowe GM, McGarvey DJ, Mortensen A, Phillip DM, Truscott TG et al. Carotenoid radical chemistry and antioxidant/prooxidant properties. Arch Biochem Biophys 2004; 430: 37 - 48

120 Demmig-Adams B, Gilmore AM, Adams III WW. Carotenoids 3: in vivo function of carotenoids in higher plants. FASEB J 1996; 10: $403-12$

121 Demmig-Adams B, Adams III WW. Antioxidants in photosynthesis and human nutrition. Science 2002; 298: 2149-53

122 Stahl W, Sies $H$. Carotenoids and flavonoids contribute to nutritional protection against skin damage from sunlight. Mol Biotechnol 2007; 37: $26-30$

123 Stahl W, Heinrich U, Aust O, Tronnier H, Sies H. Lycopene-rich products and dietary photoprotection. Photochem Photobiol Sci 2006; 5: $238-42$

124 Stahl W, Heinrich U, Wiseman S, Eichler O, Sies H, Tronnier H. Dietary tomato paste protects against ultraviolet light-induced erythema in humans. J Nutr 2001; 131: 1449- 51

125 Heinrich U, Gärtner C, Wiebusch M, Eichler O, Sies H, Tronnier H et al. Supplementation with beta-carotene or a similar amount of mixed carotenoids protects humans from UV-induced erythema. J Nutr 2003; 133: 98 - 101

126 Fahey JW, Stephenson KK, Dinkova-Kostova AT, Egner PA, Kensler TW, Talalay $P$. Chlorophyll, chlorophyllin and related tetrapyrroles are significant inducers of mammalian phase 2 cytoprotective genes. Carcinogenesis 2005; 26: 1247-55

127 Khachik F, Bertram JS, Huang M-T, Fahey JW, Talalay P. Dietary carotenoids and their metabolites as potentially useful chemoprotective agents against cancer. In: Packer L, Hiramatsu M, Yoshikawa T, editors. Proceedings of the International Symposium on Antioxidant Food Supplements in Human Health Oxford: Academic Press; 1999: $203-29$ 
128 Fahey JW, Zalcmann AT, Talalay P. The chemical diversity and distribution of glucosinolates and isothiocyanates among plants. Phytochemistry 2001; 56: 5 - 51

129 Wittstock U, Halkier BA. Glucosinolate research in the Arabidopsis era. Trends Plant Sci 2002; 7: 263 - 70

130 Halkier BA, Gershenzon J. Biology and biochemistry of glucosinolates. Annu Rev Plant Biol 2006; 57: 303 - 33

131 Wittstock U, Gershenzon J. Constitutive plant toxins and their role in defense against herbivores and pathogens. Curr Opin Plant Biol 2002; 5 : 300-7

132 Matusheski NV, Juvik JA, Jeffery EH. Heating decreases epithiospecifier protein activity and increases sulforaphane formation in broccoli. Phytochemistry 2004; 65: $1273-81$

133 Shapiro TA, Fahey JW, Wade KL, Stephenson KK, Talalay P. Human metabolism and excretion of cancer chemoprotective glucosinolates and isothiocyanates of cruciferous vegetables. Cancer Epidemiol Biomarkers Prev 1998; 7: 1091 - 100

134 Shapiro TA, Fahey JW, Wade KL, Stephenson KK, Talalay P. Chemoprotective glucosinolates and isothiocyanates of broccoli sprouts: metabolism and excretion in humans. Cancer Epidemiol Biomarkers Prev 2001; 10: $501-8$

135 Zhang Y, Cho CG, Posner GH, Talalay P. Spectroscopic quantitation of organic isothiocyanates by cyclocondensation with vicinal dithiols. Anal Biochem 1992; 205: 100-7

136 Zhang Y, Wade KL, Prestera T, Talalay P. Quantitative determination of isothiocyanates, dithiocarbamates, carbon disulfide, and related thiocarbonyl compounds by cyclocondensation with 1,2-benzenedithiol. Anal Biochem 1996; 239: $160-7$

137 Shapiro TA, Fahey JW, Dinkova-Kostova AT, Holtzclaw WD, Stephenson KK, Wade KL et al. Safety, tolerance, and metabolism of broccoli sprout glucosinolates and isothiocyanates: a clinical phase I study. Nutr Cancer 2006; 55: 53-62

138 Zhang Y, Talalay P, Cho CG, Posner GH. A major inducer of anticarcinogenic protective enzymes from broccoli: isolation and elucidation of structure. Proc Natl Acad Sci USA 1992; 89: 2399 - 403

139 Zhang Y, Tang L. Discovery and development of sulforaphane as a cancer chemopreventive phytochemical. Acta Pharmacol Sin 2007; 28: $1343-54$

140 Talalay P, Dinkova-Kostova AT, Holtzclaw WD. Importance of phase 2 gene regulation in protection against electrophile and reactive oxygen toxicity and carcinogenesis. Adv Enzyme Regul 2003; 43: 121 34

141 Nguyen T, Yang CS, Pickett CB. The pathways and molecular mechanisms regulating Nrf2 activation in response to chemical stress. Free Radic Biol Med 2004; 37: 433 - 41

142 Motohashi H, Yamamoto M. Nrf2-Keap1 defines a physiologically important stress response mechanism. Trends Mol Med 2004; 10: 549 57

143 Dinkova-Kostova AT, Holtzclaw WD, Kensler TW. The role of Keap1 in cellular protective responses. Chem Res Toxicol 2005; 18: 1779-91

144 Kensler TW, Wakabayashi N, Biswal S. Cell survival responses to environmental stresses via the Keap1-Nrf2-ARE pathway. Annu Rev Pharmacol Toxicol 2007; 47: 89-116

145 Fahey JW, Talalay P. Antioxidant functions of sulforaphane: a potent inducer of Phase II detoxication enzymes. Food Chem Toxicol 1999; 37: $973-9$

146 Dinkova-Kostova AT, Jenkins SN, Fahey JW, Ye L, Wehage SL, Stephenson KK et al. Protection against UV-light-induced skin carcinogenesis in SKH-1 high-risk mice by sulforaphane-containing broccoli sprout extracts. Cancer Lett 2006; 240: $243-52$

147 Thejass P, Kuttan G. Immunomodulatory activity of sulforaphane, a naturally occurring isothiocyanate from broccoli (Brassica oleracea). Phytomedicine 2007; 14: 538-45

148 Kim HJ, Barajas B, Wang M, Nel AE. Nrf2 activation by sulforaphane restores the age-related decrease of $\mathrm{T}(\mathrm{H}) 1$ immunity: Role of dendritic cells. J Allergy Clin Immunol, in press
149 Talalay P, Fahey JW, Healy ZR, Wehage SL, Benedict AL, Min C et al. Sulforaphane mobilizes cellular defenses that protect skin against damage by UV radiation. Proc Natl Acad Sci USA 2007; 104: 17500-5

150 Dinkova-Kostova AT, Fahey JW, Wade KL, Jenkins SN, Shapiro TA, Fuchs $E J$ et al. Induction of the phase 2 response in mouse and human skin by sulforaphane-containing broccoli sprout extracts. Cancer Epidemiol Biomarkers Prev 2007; 16: 847 - 51

151 Reichrath J. Vitamin D and the skin: an ancient friend, revisited. Exp Dermatol 2007; 16: 618-25

152 Han SS, Keum YS, Seo HJ, Chun KS, Lee SS, Surh YJ. Capsaicin suppresses phorbol ester-induced activation of NF-kappaB/Rel and AP-1 transcription factors in mouse epidermis. Cancer Lett 2001; 164: 119-26

153 Surh YJ. Cancer chemoprevention with dietary phytochemicals. Nat Rev Cancer 2003; 3: 768-80

154 Garssen J, Buckley TL, Van Loveren H. A role for neuropeptides in UVBinduced systemic immunosuppression. Photochem Photobiol 1998; 68: $205-10$

155 Hart PH, Townley SL, Grimbaldeston MA, Khalil Z, Finlay-Jones JJ. Mast cells, neuropeptides, histamine, and prostaglandins in UV-induced systemic immunosuppression. Methods 2002; 28: 79-89

156 Townley SL, Grimbaldeston MA, Ferguson I, Rush RA, Zhang SH, Zhou $X F$ et al. Nerve growth factor, neuropeptides, and mast cells in ultraviolet-B-induced systemic suppression of contact hypersensitivity responses in mice. J Invest Dermatol 2002; 118: 396-401

157 Howes RA, Halliday GM, Barnetson RS, Friedmann AC, Damian DL. Topical capsaicin reduces ultraviolet radiation-induced suppression of Mantoux reactions in humans. J Dermatol Sci 2006; 44: 113 -5

158 Baur JA, Sinclair DA. Therapeutic potential of resveratrol: the in vivo evidence. Nat Rev Drug Discov 2006; 5: 493-506

159 Cantos E, Espín JC, Tomás-Barberán FA. Postharvest induction modeling method using UV irradiation pulses for obtaining resveratrol-enriched table grapes: a new "functional" fruit? J Agric Food Chem 2001; 49: $5052-8$

160 Versari A, Parpinello GP, Tornielli GB, Ferrarini R, Giulivo C. Stilbene compounds and stilbene synthase expression during ripening, wilting, and UV treatment in grape cv. Corvina. J Agric Food Chem 2001; 49: $5531-6$

161 Adhami VM, Afaq F, Ahmad N. Suppression of ultraviolet B exposuremediated activation of NF-kB in normal human keratinocytes by resveratrol. Neoplasia 2003; 5: 74-82

162 Park K, Lee JH. Protective effects of resveratrol on UVB-irradiated HaCaT cells through attenuation of the caspase pathway. Oncol Rep 2008; 19: $413-7$

163 Afaq F, Adhami VM, Ahmad N. Prevention of short-term ultraviolet B radiation-mediated damages by resveratrol in SKH-1 hairless mice. Toxicol Appl Pharmacol 2003; 186: 28 - 37

164 Reagan-Shaw S, Afaq F, Aziz MH, Ahmad N. Modulations of critical cell cycle regulatory events during chemoprevention of ultraviolet Bmediated responses by resveratrol in SKH-1 hairless mouse skin. Oncogene 2004; 23: $5151-60$

165 Aziz MH, Reagan-Shaw S, Wu J, Longley BJ, Ahmad N. Chemoprevention of skin cancer by grape constituent resveratrol: relevance to human disease? FASEB J 2005; 19: 1193 - 5

166 Barthelman M, Chen W, Gensler HL, Huang C, Dong Z, Bowden GT. Inhibitory effects of perillyl alcohol on UVB-induced murine skin cancer and AP-1 transactivation. Cancer Res 1998; 58: 711-6

167 Haridas $V$, Hanausek M, Nishimura G, Soehnge $H$ et al. Triterpenoid electrophiles (avicins) activate the innate stress response by redox regulation of a gene battery. J Clin Invest 2004; 113: 65 - 73

168 Creelman RA, Mullet JE. Oligosaccharins, brassinolides, and jasmonates: nontraditional regulators of plant growth, development, and gene expression. Plant Cell 1997; 9: 1211 - 23

169 Strickland FM, Darvill A, Albersheim P, Eberhard S, Pauly M, Pelley RP. Inhibition of UV-induced immune suppression and interleukin-10 production by plant oligosaccharides and polysaccharides. Photochem Photobiol 1999; 69: 141 - 7

170 Strickland FM. Immune regulation by polysaccharides: implications for skin cancer. J Photochem Photobiol B 2001; 63: 132 - 40 